\title{
Food web studies in a Norwegian kelp forest based on stable isotope $\left(\delta^{13} \mathrm{C}\right.$ and $\left.\delta^{15} \mathrm{~N}\right)$ analysis
}

\author{
Stein Fredriksen* \\ Department of Biology, Section for Marine Biology and Limnology, PO Box 1069, Blindern, 0316 Oslo, Norway
}

\begin{abstract}
Samples of kelp Laminaria hyperborea, various species of red algae, phytoplankton, material from sediment traps, invertebrates, fish and seabirds were collected on the west coast of Norway and the abundance of stable isotopes was analyzed. Canopy plants of L. hyperborea were most ${ }^{13} \mathrm{C}$ depleted in spring and there was a significant difference between the basal $\left({ }^{13} \mathrm{C}:-16.65 \%\right)$ and distal $\left(\delta^{13} \mathrm{C}:-18.67 \%\right)$ parts of the lamina. Young kelp plants were more ${ }^{13} \mathrm{C}$ depleted $(-23.59 \%)$. The red algae fell into 2 groups: one in the same range as kelp plants $\left(\delta^{13} \mathrm{C}:-18.93\right.$ to $\left.-22.27 \%\right)$ and the other highly depleted $\left(\delta^{13} \mathrm{C}:-32.85\right.$ to $-34.38 \%$ ). Phytoplankton showed an average $\delta^{13} \mathrm{C}$ value of $-24.44 \%$. $\delta^{15} \mathrm{~N}$ values from $L$. hyperborea differed between the basal $\left(\delta^{15} \mathrm{~N}: 5.54 \%\right)$ and distal $\left(\delta^{15} \mathrm{~N}\right.$ : $3.54 \%$ ) part of lamina. $\delta^{15} \mathrm{~N}$ values for all primary producers values were in the range of 3.52 to $5.78 \%$. Among the gastropods, Helcion pellucida proved to be a kelp plant grazer, Lacuna vincta probably fed on both kelp and various species of red algae, whereas Aplysia punctata grazed exclusively on the most ${ }^{13} \mathrm{C}$-depleted red algae. $\delta^{15} \mathrm{~N}$ values for 2 other gastropods, Gibbula sp. and Calliostoma zizyphinum (8.64 and $10.30 \%$, respectively), suggest that they belong to higher trophic levels. Filter feeders occupied lower trophic levels and received variable carbon inputs from kelp. The only group of animals with $\delta^{13} \mathrm{C}$ signals in the same range as phytoplankton were amphipods. Based on $\delta^{15} \mathrm{~N}$ values, the fish varied from intermediate to top consumers (trophic level: 2.6 to 3.3). Two species of seabirds were included in the study and their $\delta^{15} \mathrm{~N}$ values suggested 2 different trophic levels, which correspond to their known feeding preferences. A mixing model suggests that kelp-derived carbon plays an important role in this nearshore system and that kelp may serve as a carbon source for marine animals with several different types of feeding strategies.
\end{abstract}

KEY WORDS: $\delta^{13} \mathrm{C} \cdot \delta^{15} \mathrm{~N} \cdot$ Algae $\cdot$ Animals $\cdot$ Food webs Resale or republication not permitted without written consent of the publisher

\section{INTRODUCTION}

Many researchers have addressed questions about marine food webs by studying ratios of naturally occurring stable carbon $\left({ }^{13} \mathrm{C} /{ }^{12} \mathrm{C}\right)$ and nitrogen $\left({ }^{15} \mathrm{~N} /{ }^{14} \mathrm{~N}\right)$ isotopes (e.g. Dunton \& Schell 1987, Hobson \& Welch 1992, Dauby et al. 1998, Kaelher et al. 2000, Lesage et al. 2001, Jennings et al. 2002). Conventional dietary analysis only provides measurements of ingested food, whereas stable isotope analysis has the advantage of providing time-integrated averages of assimilated food (Fry 1988, Rau et al. 1992, Hobson et al. 1995, Vander Zanden et al. 1999). The 2 isotopes can be used in different ways. Fractionation of ${ }^{13} \mathrm{C}$ is limited to about $1 \%$ per trophic level, and it can therefore be used to iden- tify ultimate carbon sources (Fry \& Sherr 1984, Peterson et al. 1985). Conversely, the ${ }^{15} \mathrm{~N}$ content of consumers is typically enriched by 3 to $4 \%$ relative to their prey and the results can be used to construct trophic relationships in systems where feeding relationships are unknown (Hobson \& Welch 1992, Vander Zanden \& Rasmussen 1999). Thus, combined measurements of $\mathrm{C}$ and $\mathrm{N}$ isotopes can provide information on both source materials and food web structure.

Along the coasts of Europe, the kelp forest is dominated by Laminaria hyperborea (Gunn.)Foslie, a species which is distributed from Portugal in the south (Kain 1971) to the Murman coast in the north (Schoschina 1997). This kelp forest provides a habitat for a diverse number of marine animals and Christie et 
al. (1998) found a rich fauna of mobile invertebrates associated with the epiphytic algae on the kelp stipe. Moreover, a diverse fauna inhabits the branched holdfast (Moore 1986, Schultze et al. 1990, Christie et al. 1998). What do the animals inhabiting the kelp forest consume? Production estimates for a L. hyperborea forest have been reviewed by Sjøtun et al. (1995), who calculated production to be between 1 and $4 \mathrm{~kg}$ biomass $\mathrm{m}^{-2} \mathrm{yr}^{-1}$ (dry weight) which is approximately equivalent to 3 to $12 \mathrm{~kg}$ wet $\mathrm{wt} \mathrm{m} \mathrm{m}^{-2} \mathrm{yr}^{-1}$. The estimated area covered by $L$. hyperborea along the Norwegian coast is about $5000 \mathrm{~km}^{2}$ (Fosså 1995). Using an average of $10 \mathrm{~kg}$ biomass produced (wet wt) $\mathrm{m}^{-2} \mathrm{yr}^{-1}$, the calculated total production equals $50 \times 10^{6} \mathrm{t}$ kelp biomass per year along the Norwegian coast. Most of this substantial amount of biomass may enter the food chains as particulate organic material (POM), since very few animals graze directly on the kelp plant. In addition, a large fraction of the production in kelp plants is released as dissolved organic material (DOM); however, this fraction is difficult to quantify (Mann 2000). Thus, POM and DOM originating from kelps may be important in the nutrition of the animals living in the kelp forest.

Duggins \& Eckman (1997) questioned whether kelp detritus is a good food resource for suspension feeders. They found that particulate organic carbon (POC) from some species (e.g. Laminaria groenlandica) could be eaten directly, whereas POC from other species (e.g. Agarum fimbriatum) needed to be aged in order to release most of its polyphenolic secondary metabolites. Duggins et al. (1989) found that filter feeders obtain a high percentage of their carbon from kelp (up to $85 \%$ in the subtidal barnacle Balanus nubilus) and the amphipod Anonyx sp. was reported to get $100 \%$ of its carbon from kelp plants. Similar results that kelp is a major contributor to the carbon flow in a system was demonstrated by Kaehler et al. (2000).

This paper presents the results of isotopic analyses $\left(\delta^{13} \mathrm{C}\right.$ and $\left.\delta^{15} \mathrm{~N}\right)$ of components of food webs in a nearshore kelp forest system in Norway, in relation to the following questions: (1) Because Laminaria hyperborea has a strong seasonal growth cycle with maximum growth in winter and spring and no growth in summer, will this be reflected in isotope signals $\left(\delta^{13} \mathrm{C}\right.$ and $\delta^{15} \mathrm{~N}$ ) in the kelp? (2) Is the kelp itself an important carbon source in this system? (3) What is the trophic status of common animals in this system?

\section{MATERIALS AND METHODS}

Sampling. Haphazard samples of the kelp Laminaria hyperborea, various species of red algae and animals were collected using SCUBA near the island of Finnøy on the west coast of Norway (Fig. 1). Sampling took place from August 1995 to May 1997. Material was collected from 2 sites separated by approximately $1000 \mathrm{~m}$, and at depths around $5 \mathrm{~m}$ at both sites.

As a result of erosion, the distal part of the lamina in kelp plants will be a continuous source of POM. Samples were taken from both the meristematic zone and the distal end by cutting out discs ( $2 \mathrm{~cm}$ in diameter), 2 from the basal part (pooled prior to isotope analysis) and 2 from the distal part (pooled prior to isotope analysis) of the lamina. Due to the very pronounced growth cycle of Laminaria hyperborea (Schaffelke \& Lüning 1994), 10 plants were sampled on each of the 4 seasonal visits (Aug 95, Nov 95, Mar 96, Jun 96), 5 from each sampling site on 2 consecutive days. In addition, 5 young understorey plants (lamina $<10 \mathrm{~cm}$ ) of $L$. hyperborea were selected from both sampling sites on each visit except in November 1995. The entire lamina of the small plants was used in the isotope analysis. The lamina samples were frozen and then transported back to the lab where they were dried at $50^{\circ} \mathrm{C}$ and subsequently ground to a fine powder. Red algae were collected both from the rocky substrate between the kelps and from kelp stipes and laminas from both sampling sites. Whole or large pieces of red algae free of epiphytes were treated in the same way as lamina samples of L. hyperborea.

Most of the animals were sampled in September 1996 at depths between 2 and $10 \mathrm{~m}$. Mobile and sessile invertebrates associated with kelp stipes were caught by first cutting off the lamina, then carefully placing a net over the stipe, loosening the holdfast from the bottom and closing the net at both ends with a rope. Three stipes were collected from each sampling site. Back on land, the mobile invertebrates could be picked from the net, while the sessile ones (bryozoans, hydroids, tunicates) were carefully removed from the stipes. All invertebrates from the 6 stipes were pooled. In addition, sessile and slow moving invertebrates were picked haphazardly from within the kelp forest at both sampling sites. All the invertebrates were kept alive overnight to clear their guts (Hobson \& Welch 1992). Different species were selected for further analyses and frozen. For larger species, 1 specimen was regarded as 1 replicate. In many instances, small individuals of the same species were pooled into 1 sample to obtain sufficient material for the analysis. These composites consisted of at least 3 individuals and included different animal groups such as sponges, bryozoans, mollusks and brittle stars. Amphipods were analyzed together and no attempt was made to separate them into lower taxa. When possible, soft tissue was removed from shelled organisms, but sponges, some small gastropods, bryozoans and brittle stars were soaked in $1 \mathrm{~N} \mathrm{HCl}$ for $24 \mathrm{~h}$ to remove carbonates and 


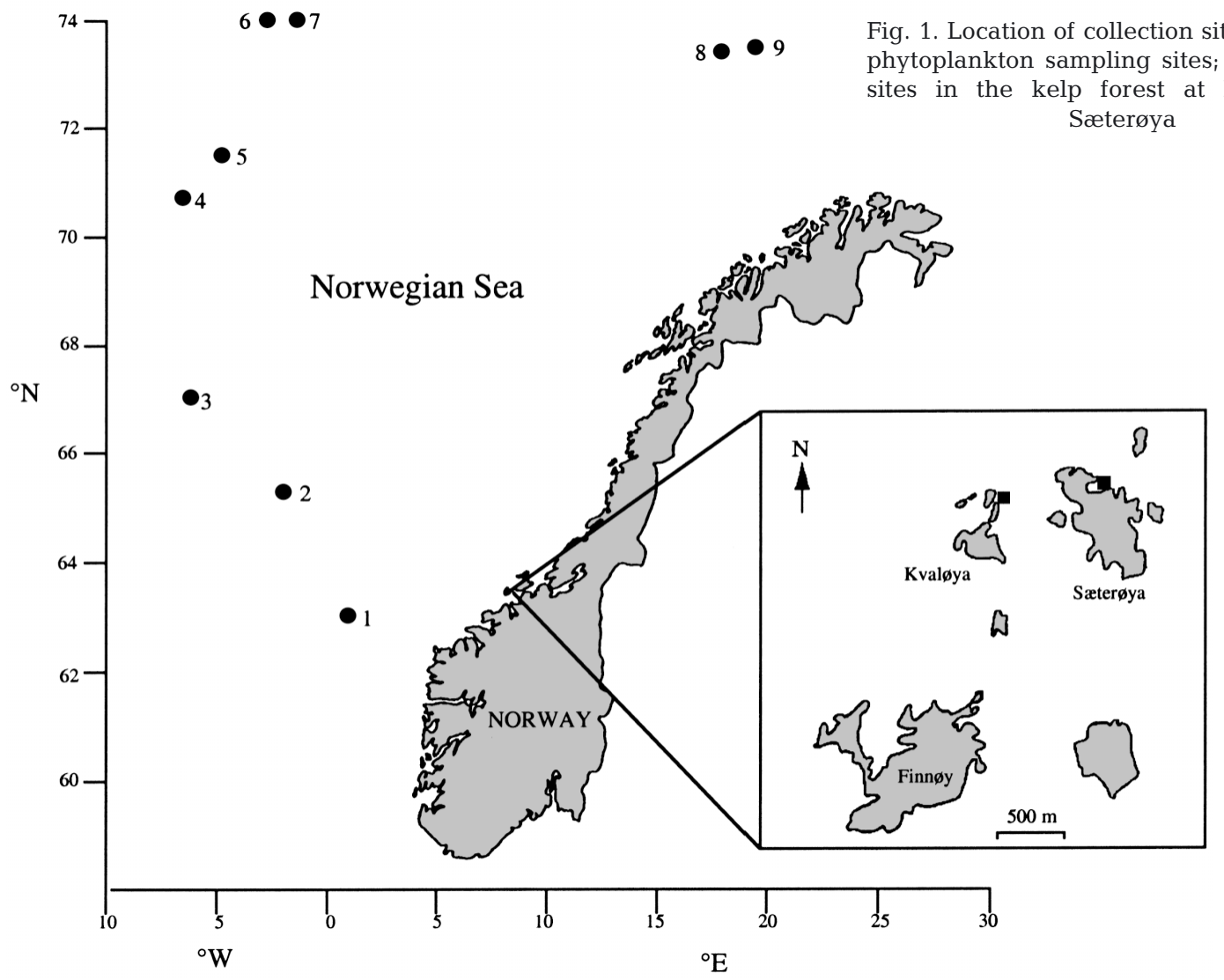

thereafter rinsed in distilled water. All samples were then dried at $50^{\circ} \mathrm{C}$ and ground to a fine powder.

Fish were caught in nets within the kelp forest at the Sæeterøya site (Fig. 1) in August 1995. Birds were shot in the area around Finnøy in August 1996. The fish and birds were sampled by cutting out a small piece of muscle (Hobson \& Welch 1992), which was then frozen, dried at $50^{\circ} \mathrm{C}$ and ground to a powder.

POM samples were obtained from sediment traps placed on the bottom ( $5 \mathrm{~m}$ depth) within the kelp forest. Five sediment traps were deployed at each sampling site for 3 mo (June to September 1996). Traps were deployed 1 to $2 \mathrm{~m}$ apart from each other at randomly picked spots and were anchored to the bottom by plugs in drilled holes. A hypersaline solution (1 kg $\mathrm{NaCl}$ in $5 \mathrm{l}$ water) with formaldehyde (10\%) was added to 10 PVC tubes $(25 \mathrm{~cm}$ high, $4.5 \mathrm{~cm}$ internal diameter) to prevent bacterial growth and degradation. The traps were capped in situ and retrieved by divers. Samples were filtered through a $1 \mathrm{~mm}$ filter, and the filtrate was frozen and returned to the lab. After thawing, the filtrate was diluted in seawater for $24 \mathrm{~h}$ to remove the formaldehyde. It was then filtered once again through a $200 \mu \mathrm{m}$ mesh filter, dried and ground to a powder.
Phytoplankton samples were collected in March and June 1996 in the nearshore waters close to the 2 Laminaria hyperborea sites. The samples were full of debris (probably originating from kelp plants), and consequently did not represent the isotopic composition of phytoplankton alone. The debris was believed to influence the isotopic composition of these samples considerably. In fall 1996, it was therefore decided to sample phytoplankton at a number of localities during an offshore cruise in the Norwegian Sea (Fig. 1) in the period from 28 April to 8 May 1997. Additional sampling was carried out in the nearshore waters in April 1997, during the spring bloom period. In all cases, a plankton net with a mesh size of $20 \mu \mathrm{m}$ was towed for about $10 \mathrm{~min}$ through the surface waters. Samples were filtered through pre-combusted GF/C filters and frozen. Entire filters were ground to a powder prior to analysis.

Isotopic analyses. The prepared samples (kelp, red algae, phytoplankton, invertebrates, fish, birds and sediment trap material) were combusted in sealed tin capsules in an elementary analyzer (Carlo Erba NA 1500). The combustion products, $\mathrm{CO}_{2}, \mathrm{~N}_{2}$ and $\mathrm{H}_{2} \mathrm{O}$, were separated in cryogenic traps, leaving pure $\mathrm{CO}_{2}$ and $\mathrm{N}_{2}$ to be analyzed on-line in a mass spectrome- 
ter (Finnigan MAT Delta E: accuracy 0.2\%). The ratios ${ }^{13} \mathrm{C} /{ }^{12} \mathrm{C}$ or ${ }^{15} \mathrm{~N} /{ }^{14} \mathrm{~N}$ were measured against a machine standard that had previously been calibrated against international standards (NBS22 for $\delta^{13} \mathrm{C}$, IAEA N1 for $\left.\delta^{15} \mathrm{~N}\right) . \delta^{13} \mathrm{C}$ and $\delta^{15} \mathrm{~N}$ values are reported relative to PDB and atmospheric air, respectively. Results are expressed in the standard delta notation as:

$$
\delta X=\left[\left(R_{\text {sample }} / R_{\text {standard }}\right)-1\right] \times 1000
$$

where $X$ is either $\mathrm{C}$ or $\mathrm{N}$ and $R$ is the ratio of the heavy to the light isotope. Analyses were performed by the GMS laboratory at the Department of Geology, University of Bergen, Norway.

Trophic position. Trophic position was calculated according to a model developed by Hobson \& Welch (1992):

$$
\mathrm{TL}=1+(\mathrm{Dm}-4.4) / 3.8
$$

where TL is the trophic level of the consumer, Dm is the $\delta^{15} \mathrm{~N} \%$ value of the consumer, 4.4 is the average $\delta^{15} \mathrm{~N}(\%)$ of the primary producers (adult kelp plants and phytoplankton) and 3.8 is the $\delta^{15} \mathrm{~N}(\%)$ enrichment value per trophic level. According to Hobson \& Welch (1992), an enrichment value of $2.4 \%$ should be used for birds because they produce uric acid instead of urea. A TL close to 1 indicates a herbivore species, while TL $>2$ indicates a carnivorous diet.

Determination of carbon source. The vast majority of all photosynthesized carbon in a kelp system probably originates from either kelp or phytoplankton (Dunton \& Dayton 1995, Mann 2000). To estimate the carbon contribution made by kelp in this system, the mixing equation of McConnaughey \& McRoy (1979) was used:

$\% \mathrm{C}_{\text {kelp-derived }}=\frac{\left(\delta^{13} \mathrm{C}_{\text {consumer }}-\delta^{13} \mathrm{C}_{\text {phytoplankton }}-I\right) \times 100}{\delta^{13} \mathrm{C}_{\text {kelp }}-\delta^{13} \mathrm{C}_{\text {phytoplankton }}}$

where $I$ is the average post-photosynthetic fractionation of $\delta^{13} \mathrm{C}$ per trophic level. In the current study, the value $0.8 \%$ was chosen because according to DeNiro \& Epstein (1978), the average increase in $\delta^{13} \mathrm{C}$ is $0.8 \%$ per trophic level in animals relative to their diet. This implies that $I=0.8 \times$ trophic level for each animal. The value used for kelp is the average from the distal and from the basal part of the lamina.

Statistics. Sampling followed a split-plot design and was analyzed by ANOVAs on log-transformed data followed by a Tukey's test (when needed) in order to determine differences between sampling dates, intralaminar and plant age variation in isotopes in Laminaria hyperborea. A Student's $t$-test was used to check for differences between 2 means. In all cases, a $95 \%$ significance level was adopted.

\section{RESULTS}

\section{Isotopic composition of Laminaria hyperborea}

$$
\delta^{13} \mathrm{C}
$$

No significant difference was found between the 2 sampling sites $(\mathrm{df}=1, \mathrm{MS}=0.0023, F=0.39, \mathrm{p}=$ 0.53). Table 1 shows the average $\delta^{13} \mathrm{C}$ values from the different sampling dates. A significant difference between sampling dates was found in the $\delta^{13} \mathrm{C}$ values (df $=3, \mathrm{MS}=0.035, F=6.12, \mathrm{p}=0.0009$ ) and $\mathrm{a}$ Tukey's test showed that samples from August were isotopically heavier (contain more ${ }^{13} \mathrm{C}$ ) than both November (estimate $=-0.0776$, lower bound $=$ -0.1410 , upper bound $=-0.0147$ ) and March (estimate $=-0.0972$, lower bound $=-0.1600$, upper bound $=$ $-0.0342)$. No interaction between sampling date and lamina part was found $(\mathrm{df}=3, \mathrm{MS}=0.001, F=0.31$, $\mathrm{p}=0.81$ ). The distal part of the lamina, which is the oldest part, was isotopically lighter than the younger basal part ( $\mathrm{df}=1, \mathrm{MS}=0.273, F=47.19, \mathrm{p}<0.0001$ ). The young Laminaria hyperborea plants were isotopically lighter than the mature plants (average $\delta^{13} \mathrm{C}$ values from basal and distal part) ( $\mathrm{df}=1, \mathrm{MS}=1.307, F=$ 280.18, p < 0.0001). However, unlike the mature plants, the young plants showed no significant differences with sampling date $(\mathrm{df}=2, \mathrm{MS}=0.002, F=$ $0.45, \mathrm{p}=0.63$ ).

$$
\delta^{15} \mathrm{~N}
$$

No significant difference was found between the 2 sampling sites ( $\mathrm{df}=1, \mathrm{MS}=0.006, F=0.36, \mathrm{p}=$ 0.55). Table 2 shows the $\delta^{15} \mathrm{~N}$ values in kelp plants from the different sampling dates. A significant difference between sampling dates was found $(\mathrm{df}=3, \mathrm{MS}=$ $0.11, F=6.50, \mathrm{p}=0.0011$ ). The Tukey's test revealed that the samples from June were significantly different at a 0.05 level from August (estimate $=-0.1870$, lower bound $=-0.3310$, upper bound $=-0.0418$ ), November (estimate $=0.2190$, lower bound $=0.0745$,

Table 1. Laminaria hyperborea. Seasonal variation in $\delta^{13} \mathrm{C}(\%)$ values (average $\pm \mathrm{SD}, \mathrm{n}=10$ ). $\mathrm{nd}=$ no data

\begin{tabular}{|lccc|}
\hline $\begin{array}{l}\text { Sampling } \\
\text { date }\end{array}$ & $\begin{array}{c}\text { Mature plants, } \\
\text { basal part }\end{array}$ & $\begin{array}{c}\text { Mature plants, } \\
\text { distal part }\end{array}$ & $\begin{array}{c}\text { Young } \\
\text { plants }\end{array}$ \\
\hline Aug 95 & $-15.76 \pm 1.54$ & $-17.62 \pm 1.12$ & $-24.24 \pm 0.72$ \\
Nov 95 & $-17.19 \pm 1.37$ & $-18.81 \pm 0.72$ & nd \\
Mar 96 & $-17.26 \pm 1.93$ & $-19.56 \pm 1.33$ & $-22.97 \pm 1.79$ \\
Jun 96 & $-16.39 \pm 1.09$ & $-18.73 \pm 1.22$ & $-23.57 \pm 2.48$ \\
Average & $-16.65 \pm 1.58$ & $-18.67 \pm 1.28$ & $-23.59 \pm 1.83$ \\
\hline
\end{tabular}


upper bound $=0.3640$ ) and March (estimate $=0.1600$, lower bound $=0.0153$, upper bound $=0.3050$ ). The distal part of the lamina was isotopically lighter than the basal part $(\mathrm{df}=1, \mathrm{MS}=2.534, F=144.87, \mathrm{p}<$ 0.0001). An interaction was found between sampling dates and part of the lamina ( $\mathrm{df}=3, \mathrm{MS}=0.243, F=$ 13.88, $\mathrm{p}<0.0001$ ) showing that differences in $\delta^{15} \mathrm{~N}$ in distal and basal parts of the lamina varied with season. A significant difference $(\mathrm{df}=1, \mathrm{MS}=0.754, F=$ $6.51, \mathrm{p}=0.016$ ) was found between the young plants and the average of the basal and distal part of the old plants. Again, no difference was found in the young plants with sampling date $(\mathrm{df}=2, \mathrm{MS}=0.249, F=$ $2.14, \mathrm{p}=0.13)$.

\section{Isotopic composition of phytoplankton}

The average $\delta^{13} \mathrm{C}$ value from the inshore waters in March 1996 was $-17.50 \% \pm 0.37$ (SD) $(\mathrm{n}=2)$, in June 1996 was $-18.43 \% \pm 0.09(\mathrm{n}=3)$, and in the spring bloom period April 1997 was -21.65\% \pm 0.01 ( $n=10)$. The average value from the Norwegian Sea (28 April to 8 May) was $-24.44 \% \pm 2.00(n=9)$. Values from the Norwegian Sea are chosen to represent pure phytoplankton because samples from inshore waters contained unidentified particles that could have been POC from the kelp forest. $\delta^{15} \mathrm{~N}$ values were only analyzed for the offshore samples, and they were in the same range as for kelp plants and red algae (average $4.47 \%$ o $1.11, \mathrm{n}=4)$.

\section{Isotopic composition of red algae}

$$
\delta^{13} \mathrm{C}
$$

The species of red algae examined fell into 2 distinct groups. One group had $\delta^{13} \mathrm{C}$ values close to those found in mature kelps (from -18.93 to $-22.27 \%$ ), whereas the other was isotopically much lighter, with $\delta^{13} \mathrm{C}$ values from -32.86 to $-34.38 \%$ (Table 3, Fig. 2).

Table 2. Laminaria hyperborea. Seasonal variation in $\delta^{13} \mathrm{~N}$ $(\%)$ values (average $\pm S D, n=6$ ). nd $=$ no data

\begin{tabular}{|lccc|}
\hline $\begin{array}{l}\text { Sampling } \\
\text { date }\end{array}$ & $\begin{array}{c}\text { Mature plants, } \\
\text { basal part }\end{array}$ & $\begin{array}{c}\text { Mature plants, } \\
\text { distal part }\end{array}$ & $\begin{array}{c}\text { Young } \\
\text { plants }\end{array}$ \\
\hline Aug 95 & $6.12 \pm 0.29$ & $2.85 \pm 0.33$ & $2.79 \pm 0.75$ \\
Nov 95 & $5.47 \pm 0.64$ & $3.03 \pm 0.49$ & nd \\
Mar 96 & $4.61 \pm 0.75$ & $4.03 \pm 0.25$ & $4.05 \pm 1.77$ \\
Jun 96 & $5.97 \pm 0.33$ & $4.26 \pm 0.59$ & $4.86 \pm 1.86$ \\
Average & $5.54 \pm 0.82$ & $3.54 \pm 0.77$ & $3.83 \pm 1.78$ \\
\hline
\end{tabular}

\section{$\delta^{15} \mathrm{~N}$}

The results from the red algae showed average values in the range from 5.03 to $5.78 \%$ o (Table 3 ).

\section{Isotopic composition of material from sediment traps}

The composition of material found in sediment traps included small fragments of both Laminaria spp. and various species of red algae. No significant difference was found between the 2 sampling sites for either $\delta^{13} \mathrm{C}$ $(\mathrm{p}=0.49, \mathrm{n}=5)$ or $\delta^{15} \mathrm{~N}(\mathrm{p}=0.32, \mathrm{n}=3)$. The average $\delta^{13} \mathrm{C}$ value for all 10 traps was $-17.55 \%$ o \pm 0.82 (Table 3), which is in the same range as kelp. The $\delta^{15} \mathrm{~N}$ values also proved to be in the same range as for the primary producers (average $4.85 \% \pm 0.13$ ).

\section{Isotopic composition of animals}

Most gastropods appeared to be herbivores. Several representatives of this highly diverse group are present in a kelp forest, including Helcion pellucida, Lacuna vincta and Gibbula sp., which were all frequently found on the lamina of kelp plants. Of these, Helcion pellucida was almost exclusively found on the lamina (often the basal part), and had a $\delta^{13} \mathrm{C}$ signal close to that of kelp plants $\left(-16.16 \%\right.$ ), and a $\delta^{15} \mathrm{~N}$ signal in the kelp range (5.33\%o, trophic level 1.2). The results from the mixing equation showed that $H$. pellucida obtained $100 \%$ of its carbon from kelp. L. vincta, which were found on both kelp plants and red algae, had a slightly more negative $\delta^{13} \mathrm{C}$ signal $(-19.06 \%)$, suggesting that its diet consists of both kelp (60\%) and red algae. The $\delta^{15} \mathrm{~N}$ signal (6.56\%, trophic level 1.6) of L. vincta suggests that it feeds mainly on algae, but also on animals to some extent. The opisthobranch Aplysia punctata was typically found on various species of red algae. Both the $\delta^{13} \mathrm{C}\left(-30.97 \%\right.$ o) and the $\delta^{15} \mathrm{~N}$ (5.56\%, trophic level 1.3) values suggested that this species feeds on the isotopically lightest group of red algae (see Fig. 2). The mixing model suggests that $0 \%$ of the carbon in the A. punctata diet is kelp derived. Another grazing organism is the sea urchin Echinus esculentus. This species had a $\delta^{13} \mathrm{C}$ value of $-19.92 \%$, indicating a mixed diet including both kelp $(47 \%$ according to the mixing model) and red algae; however, its trophic level (1.7) indicates that it eats other organisms in addition to algae.

The filter feeders comprise many groups of animals such as sponges, hydroids, bivalves, bryozoans, brittle stars and tunicates. Their $\delta^{13} \mathrm{C}$ values ranged from the isotopically heaviest bivalve Hiatella arctica (-19.32\%) to the isotopically lightest cnidarian Tubularia larynx 
Table 3. $\delta^{13} \mathrm{C}$ and $\delta^{15} \mathrm{~N}(\%)$ values, trophic level of organisms investigated and \% kelp carbon from the mixing model. Trophic level is based on an isotopic model using $\delta^{15} \mathrm{~N}$ trophic enrichment values of $+2.4 \%$ for sea birds and $+3.8 \%$ for other animals. *Several individuals pooled to obtain sufficient material for the analysis. nd: no data

\begin{tabular}{|c|c|c|c|c|c|c|c|c|}
\hline & $\mathrm{n}$ & $\begin{array}{l}\text { Average } \\
\delta^{13} \mathrm{C} \% \text { o }\end{array}$ & $\mathrm{SD}$ & $\mathrm{n}$ & $\begin{array}{l}\text { Average } \\
\delta^{15} \mathrm{~N} \% \text { o }\end{array}$ & $\mathrm{SD}$ & $\begin{array}{c}\text { Trophic } \\
\text { level }\end{array}$ & $\begin{array}{l}\% \text { kelp } \\
\text { carbon }\end{array}$ \\
\hline \multicolumn{9}{|l|}{ Algae } \\
\hline \multicolumn{9}{|l|}{ Phaeophyceae } \\
\hline L. hyperborea (Gunn.) Foslie. Basal & 40 & -16.65 & 1.58 & 24 & 5.54 & 0.82 & & \\
\hline L. hyperborea (Gunn.) Foslie. Distal & 40 & -18.67 & 1.28 & 24 & 3.54 & 0.77 & & \\
\hline L. hyperborea (Gunn.) Foslie. Young & 30 & -23.59 & 1.83 & 18 & 3.83 & 1.78 & & \\
\hline Saccorhiza polyschides (Lightf.) Batt. & 4 & -16.66 & 0.80 & & nd & & & \\
\hline \multicolumn{9}{|l|}{ Rhodophyceae } \\
\hline Palmaria palmata (L.) Kuntze & 19 & -18.93 & 2.12 & 6 & 5.31 & 1.43 & & \\
\hline Rhodomela confervoides (Huds.) Silva & 4 & -22.27 & 0.71 & 4 & 5.72 & 0.40 & & \\
\hline Callophyllis laciniata (Huds.) Kütz. & 5 & -32.86 & 2.08 & 4 & 5.03 & 0.65 & & \\
\hline Delesseria sanquinea (Huds.) Lamour. & 10 & -33.64 & 0.88 & 6 & 5.78 & 0.49 & & \\
\hline Membranoptera alata (Huds.) Stackh. & 6 & -33.64 & 0.69 & 3 & 5.50 & 0.25 & & \\
\hline Phycodrys rubens (L.) Batt. & 8 & -34.38 & 1.47 & 5 & 5.46 & 0.46 & & \\
\hline Ptilota gunneri Silva. Maggs \& L. Irvine & 9 & -33.56 & 0.77 & 5 & 5.22 & 1.36 & & \\
\hline Lomentaria clavellosa (Turn.) Gaill. & 3 & -33.69 & 0.95 & & nd & & & \\
\hline Polysiphonia elongata (Huds.) Sprengel & 5 & -21.60 & 1.36 & & nd & & & \\
\hline Phytoplankton & 9 & -24.44 & 2.01 & 4 & 4.47 & 1.11 & & \\
\hline Sediment traps & 10 & -17.55 & 0.82 & 6 & 4.85 & 0.13 & & \\
\hline \multicolumn{9}{|l|}{ Invertebrates } \\
\hline \multicolumn{9}{|l|}{ Porifera } \\
\hline Scypha compressa (Fabricius) ${ }^{*}$ & 7 & -19.93 & 0.21 & 7 & 5.52 & 0.91 & 1.3 & 51 \\
\hline \multicolumn{9}{|l|}{ Cnidaria } \\
\hline Tubularia larynx (Ellis \& Solander) ${ }^{*}$ & 5 & -21.17 & 0.15 & 5 & 6.69 & 1.14 & 1.6 & 29 \\
\hline \multicolumn{9}{|l|}{ Annelida } \\
\hline Nereis sp. (from holdfast) & 5 & -19.14 & 0.93 & 5 & 9.66 & 0.72 & 2.4 & 50 \\
\hline \multicolumn{9}{|l|}{ Crustacea } \\
\hline Amphipoda * & 3 & -24.87 & 0.58 & 3 & 6.42 & 0.84 & 1.5 & 0 \\
\hline Cancer pagurus L. & 4 & -17.55 & 0.30 & 4 & 11.58 & 0.75 & 2.9 & 67 \\
\hline \multicolumn{9}{|l|}{ Mollusca } \\
\hline Helcion pellucidum L. ${ }^{*}$ & 10 & -16.16 & 0.48 & 6 & 5.33 & 2.15 & 1.2 & 100 \\
\hline Aplysia punctata (Cuvier) & 3 & -30.97 & 1.93 & 2 & 5.56 & 0.47 & 1.3 & 0 \\
\hline Calliostoma zizyphinum L. & 5 & -18.37 & 0.46 & 5 & 10.30 & 0.75 & 2.5 & 60 \\
\hline Gibbula sp. * & 5 & -16.18 & 0.37 & 5 & 8.64 & 0.29 & 2.1 & 97 \\
\hline Hiatella arctica L. & 2 & -19.32 & 0.04 & 2 & 7.26 & 0.43 & 1.7 & 55 \\
\hline Lacuna vincta (Montagu)* & 4 & -19.06 & 0.25 & 4 & 6.56 & 0.40 & 1.6 & 60 \\
\hline \multicolumn{9}{|l|}{ Bryozoa } \\
\hline Bugula sp.* & 5 & -21.00 & 0.40 & 5 & 5.27 & 0.80 & 1.2 & 37 \\
\hline Electra pilosa L. & 7 & -19.75 & 0.23 & 7 & 5.12 & 1.48 & 1.2 & 55 \\
\hline \multicolumn{9}{|l|}{ Echinodermata } \\
\hline Echinus esculentus L. & 4 & -19.92 & 0.87 & 4 & 7.18 & 0.95 & 1.7 & 47 \\
\hline Ophiurae spp. & 3 & -19.54 & 0.29 & 3 & 8.43 & 0.46 & 2.1 & 47 \\
\hline \multicolumn{9}{|l|}{ Chordata } \\
\hline \multicolumn{9}{|l|}{ Tunicata } \\
\hline Botryllus schlosseri (Pallas) & 11 & -20.84 & 0.53 & 7 & 6.32 & 1.11 & 1.5 & 35 \\
\hline Tunicata spp. & 47 & -20.26 & 1.06 & 22 & 5.42 & 1.25 & 1.3 & 46 \\
\hline \multicolumn{9}{|l|}{ Fish } \\
\hline Centrolabrus exoletus L. & 4 & -17.93 & 0.71 & 4 & 11.45 & 0.76 & 2.8 & 63 \\
\hline Ctenolabrus rupestris L. & 2 & -17.84 & 0.28 & 2 & 10.97 & 0.98 & 2.7 & 65 \\
\hline Liparis montagui (Donovan) & 3 & -17.77 & 0.17 & 3 & 10.54 & 0.55 & 2.6 & 68 \\
\hline Microstomus kitt (Walbaum) & 2 & -17.91 & 0.37 & 2 & 10.92 & 0.44 & 2.7 & 64 \\
\hline Labrus bergylta (Ascanius) & 6 & -18.03 & 0.25 & 6 & 12.67 & 2.38 & 3.2 & 57 \\
\hline Gadus morhua L. - Open sea & 3 & -19.22 & 0.42 & 3 & 12.36 & 1.89 & 3.1 & 40 \\
\hline Gadus morhua L. - Kelp forest & 6 & -17.87 & 0.60 & 6 & 12.93 & 2.06 & 3.2 & 59 \\
\hline Pollachius pollachius L. & 3 & -18.18 & 0.48 & 3 & 13.01 & 0.26 & 3.3 & 53 \\
\hline Pollachius virens L. & 2 & -19.55 & 0.14 & 2 & 13.22 & 3.24 & 3.3 & 33 \\
\hline \multicolumn{9}{|l|}{ Birds } \\
\hline Phalacrocorax carbo L. & 1 & -18.32 & 0.00 & 1 & 12.76 & 0.00 & 4.5 & 37 \\
\hline Somateria mollissima L. & 5 & -18.22 & 1.60 & 5 & 10.54 & 1.04 & 3.6 & 49 \\
\hline
\end{tabular}


Fig. 2. $\delta^{13} \mathrm{C} \%$ values from the different carbon sources and animals representing the 3 principal types of feeding strategies in the kelp forest system. Abbreviations for sources: $\mathrm{KB}=$ kelp lamina basal; $\mathrm{KD}=$ kelp lamina distal; $\mathrm{KY}=$ young kelp plants; $\mathrm{ST}=$ sediment traps; RA = red algae; $P$ P = phytoplankton

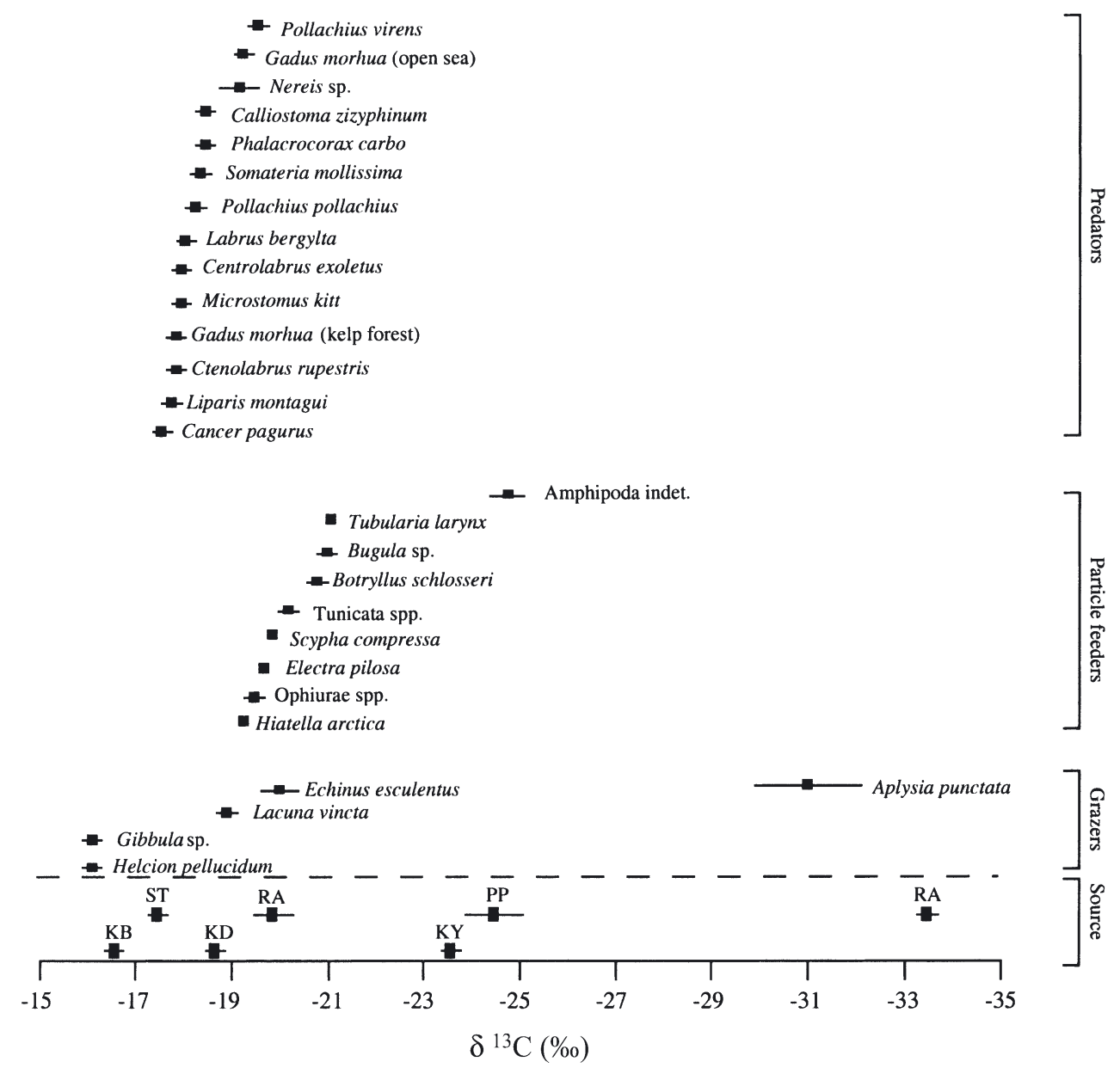

$\left(-21.17 \%\right.$ ). Common to all these groups is a $\delta^{13} \mathrm{C}$ signal which is intermediate between kelp and phytoplankton. Their $\delta^{15} \mathrm{~N}$ values suggest that they occupy low trophic levels from 1.2 (bryozoans) to 2.1 (brittle star). Results from the mixing model showed kelp-derived carbon in the range from $29 \%$ in the hydroid Tubularia larynx to $55 \%$ in the bivalve Hiatella arctica.

As a group, the amphipods were the only organisms that had $\delta^{13} \mathrm{C}$ signals in the same range as phytoplankton. The $\delta^{15} \mathrm{~N}$ signals of amphipods also suggested that they are primarily herbivores (trophic level 1.5).

The crab Cancer pagurus and the polychaete Nereis sp. both had $\delta^{15} \mathrm{~N}$ values corresponding to a higher level in the food web (trophic level 2.9 and 2.4, respectively). However, the $\delta^{13} \mathrm{C}$ values suggested that much of the carbon in their diet originates from kelp, $67 \%$ for the crab and $50 \%$ for the polychaete. Another animal with a similar isotopic signal was the gastropod Calliostoma zizyphinum. This species had a high $\delta^{15} \mathrm{~N}$ value (10.30\%, trophic level 2.5$)$, suggesting that it may be omnivorous.

The fish had $\delta^{15} \mathrm{~N}$ values corresponding to high trophic levels. They may be divided into 2 groups, one with trophic levels from 2.6 to 2.8 , and the other with trophic levels from 3.1 to 3.3. The top consumers include the cod (Gadus morhua) and the saithe (Pollachius virens), with trophic levels of 3.2 and 3.3 , respectively. The mixing model suggests kelp-derived carbon in the range from $33 \%$ (saithe) up to $68 \%$ (Liparis montagui).

Two bird species were examined, and the $\delta^{13} \mathrm{C}$ values found were $-18.32 \%$ for Phalacrocorax carbo (cormorant) and $-18.22 \%$ for Somateria mollissima (eider duck). This suggests that their carbon originates from a mixture of kelp (37\% for the cormorant and $49 \%$ for the eider duck) and phytoplankton, or from red algae. The eider duck was found to be at a lower trophic level than the cormorant (3.6 and 4.5, respectively), indicating that their feeding habits differ somewhat.

In Fig. 2, $\delta^{13} \mathrm{C}$ values for all the carbon sourceskelp, red algae, phytoplankton and sediment trapsare plotted together with the values for the various animals groups. Grazers had the greatest span in their $\delta^{13} \mathrm{C}$ signal, whereas filter feeders are more ${ }^{13} \mathrm{C}$ depleted, suggesting that their diet is more heavily based on phytoplankton. The predators are isotopically heavier, indicating that they mainly feed on animals that have kelp-derived carbon as their carbon source. 


\section{DISCUSSION}

\section{Seasonal and intra-laminar variation in isotopic signals}

Laminaria hyperborea has a pronounced growth cycle with maximum growth in winter and spring and no growth in summer. This seasonal growth pattern is caused by an endogenous circannual clock, synchronized by daylength (Schaffelke \& Lüning 1994). Variation in different isotope ratios in different parts of the tissue is caused by fractionation differences from the source to the product. This discrimination leads to marked variation in the isotope ratios of product pools at different stages of a chemical reaction (Dawson et al. 2002). Differences in isotopic ratios in parts of kelp lamina or at different dates of sampling could be caused by different biochemical reactions during the growth cycle, e.g. the interaction found between date of sampling and part of lamina for the $\delta^{15} \mathrm{~N}$. The nitrogen content in L. hyperborea is known to vary during the growth cycle (Sjøtun et al. 1996). Stephenson et al. (1984) showed that in the kelp Laminaria longicruris, no seasonal pattern in stable carbon isotope could be found, but in any given lamina there was a spatial variation. They suggested that variation in $\delta^{13} \mathrm{C}$ could be explained by storage of biochemical components of different isotopic composition. Both Dauby et al. (1998) and Raven et al. (2002) found $\delta^{13} \mathrm{C}$ signals from $L$. hyperborea to be in the same range as found in the present investigation, but did not state the part of lamina used.

Young plants were isotopically lighter than mature plants, a fact also noted by Raven et al. (2002). Kübler \& Raven (1994) showed that reduced light conditions resulted in isotopically lighter plants in 3 different species of red algae. The young kelp plants grow in the understorey, where as much as $90 \%$ of the light may be absorbed by the canopy layer (Norton et al. 1977), so young plants are restricted to light-limited conditions and as a consequence, slow growth. No seasonal variation in $\delta^{13} \mathrm{C}$ and $\delta^{15} \mathrm{~N}$ could be found in these plants. Young plants do not have a seasonal growth habit, but continue to grow throughout the summer (Sjøtun et al. 1996).

\section{Carbon sources}

In kelp forest dominated by Laminaria hyperborea, there are 2 primary carbon sources, the kelp and phytoplankton. The kelp production in the area is in the magnitude of $10 \mathrm{~kg}$ wet wt kelp $\mathrm{m}^{-2} \mathrm{yr}^{-1}$. A wet:dry weight ratio of 3:1 would imply around $3 \mathrm{~kg}$ dry wt kelp $\mathrm{m}^{-2} \mathrm{yr}^{-1}$. According to Sjøtun at al. (1996), around
$30 \%$ of the dry weight is carbon. This means a production of around $1000 \mathrm{~g} \mathrm{C} \mathrm{m}^{-2} \mathrm{yr}^{-1}$, which is more than 3 times the production by phytoplankton in the area (Mann 2000), clearly indicating that carbon from kelp could be an important source for animals living within the kelp forest system.

The most critical values in this investigation are the carbon values for phytoplankton. The values used in this study are from samples taken at some distance from the actual study sites. It was difficult to obtain pure phytoplankton values by sampling within a kelp forest, as also experienced by Kaehler et al. (2000) around the Prince Edward Islands. Dunton \& Schell (1987) found that bryozoans may act as integrators for carbon isotopes from phytoplankton. They found bryozoans with $\delta^{13} \mathrm{C}$ signals as negative as $-25.1 \%$. In the present investigation, the $\delta^{13} \mathrm{C}$ values for bryozoans ranged from -19.75 to $-21.00 \%$. This suggests that either bryozoans in this investigation do not feed exclusively on phytoplankton or the phytoplankton values within the kelp forest are different from those in the open sea. In a review paper, McKinney (1990) claims that phytoplankton appears to be the primary source of food for shallow-water bryozoans, but adds that bryozoans do not depend entirely upon phytoplankton as food. Both dissolved organic matter, including exudates from the brown algae Nereocystis luetkeana, which provides a substratum for the bryozoan Membranipora membranacea, and detritus have been demonstrated to serve as nutrient sources. Indeed, deep-water bryozoans must consume some food other than phytoplankton, most likely organic matter or perhaps resuspended sediment or detritus (see McKinney 1990 and references therein). Algae (e.g. flagellates) other than diatoms, which dominate the spring bloom, present at other times of the year may have different isotopic ratios, as documented by Rolff (2000) ( $\delta^{13} \mathrm{C}$ from -20 to $-24 \%$ ). However, the dominant POM fraction in the kelp forest in summer is kelp-derived $\left(\delta^{13} \mathrm{C}=-17.55 \%\right.$ ) , as shown by the results from the sediment traps. Recent results obtained from vertical hauls (200 to $0 \mathrm{~m}$ ) using a zooplankton net with a mesh size of $200 \mu \mathrm{m}$ in a fjord near the kelp forest area, showed $\delta^{13} \mathrm{C}$ values of $-24.12 \%$ o $( \pm 0.22 \mathrm{SD}, \mathrm{n}=6$, unpubl. results). This also strengthens the argument for using the offshore phytoplankton values.

Sediment traps used in this investigation do not follow the aspect ratio of 8 (diameter:length) recommended by Hargrave \& Burns (1979). The traps used here had an aspect ratio of 5.5. The trap data are not presented as quantitative estimates of particle flux and any bias in isotope signals due to a different aspect ratio is probably small.

It could be argued that various species of red algae may be important, but their contribution is probably of 
minor importance considering the total amount of carbon produced in the system. However, some of the red algae may be important as food. The herbivore Aplysia punctata was found to have a $\delta^{13} \mathrm{C}$ signal of $-30.97 \%$, a signal that originates from the most negative red algal group (see Fig. 2). This is supported by the frequent observations of $A$. punctata on the tetrasporophytic stage of the red algae Bonnemaisonia hamifera $\left(\delta^{13} \mathrm{C}\right.$ : -30.15 ; Raven et al. 2002), which contains highly specialized gland cells that produce antiherbivore substances. Some opisthobranchs are known for their ability to store chemical substances to make themselves venomous (Hayward et al. 1995). Dauby et al. (1998) report on another species of Aplysiidae, Aplysia depilans, to have $\delta^{13} \mathrm{C}$ signal of $-29 \%$. According to Hayward et al. (1995), Aplysia punctata is a herbivorous species feeding on different species of algae, including Laminaria.

The amphipods were treated as a group and no attempt was made to identify the different species. The $\delta^{13} \mathrm{C}$ signal for the group as a whole was $-24.87 \%$, which is within the range found for phytoplankton. However, it is uncertain whether amphipods use phytoplankton as a carbon source. Firstly, if it was feasible to identify the different amphipods to species, a wide range of feeding habits would be revealed. Some might feed on kelp debris, red algae, periphyton or phytoplankton. Secondly, amphipods are most abundant in the early fall, a period when there is little phytoplankton in the sea (Dale et al. 1999). Recent studies have shown that some of the most common amphipod species in the kelp forest like Jassa falcata, Ampithoe rubricata, Lembos websteri and Gammarus locusta can grow and survive on kelp as long as the $\mathrm{C}: \mathrm{N}$ ratio and phlorotannin content is reduced by bacterial degradation (Norderhaug et al. 2003).

\section{Food web structure}

The most important grazers found in this investigation were the gastropods. The blue-rayed limpet Helcion pellucidum had a carbon signal close to kelp $(-16.16 \%)$, indicating that this species grazes directly on the kelp plants. This limpet is often found in large numbers close to the meristematic zone on the kelp lamina. Another gastropod, the topshell Gibbula sp., had $\delta^{13} \mathrm{C}$ values close to kelp $(-16.18 \%$ ), but had a higher $\delta^{15} \mathrm{~N}$ signal than $H$. pellucida $(8.64 \%$ as compared with $5.33 \%$ ), indicating that the former is at a higher trophic level. According to Hayward et al. (1995), Gibbula sp. is a detrital sweeper. In contrast, another topshell, Callistoma zizyphinum, is considered to be a microphagous carnivore (Hayward et al. 1995), and this was confirmed by its $\delta^{13} \mathrm{C}\left(-18.37 \%\right.$ ) and $\delta^{15} \mathrm{~N}$
$(10.30 \%)$ signals. Lacuna vincta may be considered an important grazer on the kelp plants. This species can be found in enormous numbers in the fall, and can be seen grazing on holes and scars, often in the oldest part of the kelp laminas (pers. obs.). The $\delta^{13} \mathrm{C}$ signal $(-19.06 \%)$ is close to the signal of the distal part of the adult kelp plants $(-18.67 \%$ o) and the least negative group of red algae (e.g. Palmaria palmata). L. vincta has the ability to produce a mucus thread which enables the snail to drift in the water (Martel \& Diefenbach 1993), and thus move around within the kelp forest. Other grazers in a kelp forest system are sea urchins. The red urchin Echinus ecsulentus, which is common in Norwegian kelp forests, probably eats a variety of food items, and stomach analyses have shown that the species may eat anything from kelp and red algae to encrusting animals (pers. obs.).

The filter feeders have 2 main sources of carbon, POM derived from kelp and from phytoplankton. The sediment traps are believed to sample material from both of these sources. The $\delta^{13} \mathrm{C}$ signal from the traps suggests that kelp is the main source of POM in the kelp forest during summer. However, a strong phytoplankton bloom during summer is not expected (Dale et al. 1999). The filter feeders in this investigation, the sponge Scypha compressa, the bivalve Hiatella arctica, the brittle stars and the tunicates, all have $\delta^{13} \mathrm{C}$ values close to the distal part of kelp lamina. Additionally, they all have fairly non-selective feeding mechanisms. Dunton \& Schell (1987) found that Arctic hydrozoans had a strictly carnivorous diet consisting of small zooplankton and invertebrate larvae. The only hydrozoan in the present survey was Tubularia larynx, which had a $\delta^{13} \mathrm{C}$ signal of $-21.17 \%$. If zooplankton feed on phytoplankton only, this suggests that a kelp fraction must be involved in the diet of $T$. larynx; a conclusion which is further supported by the $\delta^{15} \mathrm{~N}$ value of $6.69 \%$ and a trophic level 1.6. These values do not indicate a strictly carnivorous diet (defined as trophic level $>2$ ).

The trophic positions of the different species of fish varied. The group at the lowest trophic levels consisted mainly of the Labridae (wrasses). Analyses of gut contents have shown that some species (Ctenolabrus rupestris and Centrolabrus exoletus) fed on snails (Rissoa sp. and Lacuna vincta) and different species of amphipods (Fosså et al. 1998). This corresponds well with the trophic levels (2.8 and 2.7, respectively) found in the present investigation. Another member of the Labridae, the ballan wrasse Labrus bergylta, had gut contents consisting mainly of crustaceans (Idotea spp., decapoda, amphipoda) and was at a higher trophic level (3.2) than the previously mentioned species. The pollack Pollachius pollachius was also shown to feed on crustaceans like Idotea spp. and amphipods, and its trophic level was 3.3. Cod (Gadus morhua) caught in 
the kelp forest $\left(\delta^{13} \mathrm{C}:-17.87 \%\right.$ ) were significantly ( $p=0.01$ ) more enriched in ${ }^{13} \mathrm{C}$ than cod caught in the open sea $\left(\delta^{13} \mathrm{C}:-19.22 \%\right)$, indicating that the food web in the open sea is based to a larger extent on phytoplankton. However, cod from both the kelp forest and open sea showed the same trophic position (3.2 and 3.1, respectively). Analyses of the gut contents of cod from the kelp forest showed a diet consisting of crabs and other species of fish (Fosså et al. 1998). No corresponding analysis of gut contents was carried out on fish caught in the open sea. The most ${ }^{13} \mathrm{C}$-depleted fish was the saithe Pollachius virens, which had a $\delta^{13} \mathrm{C}$ value of $-19.55 \%$. An examination of gut contents revealed that its diet consists of copepods in addition to kelp fauna (Fosså et al. 1998). Copepods are a group of zooplankton that have phytoplankton as their primary carbon source. Saithe forms small shoals and is common both in kelp forest and in the pelagic zone (Ryland 1995), probably feeding in both habitats.

The 2 seabird species included in the present study were shown to belong to significantly different trophic levels, indicating that they prefer different food. According to Witherby et al. (1965), the eider duck prefers various types of invertebrates, and in one survey, its diet was found to consist of $51 \%$ mollusks (286 Helcion pellucidum found in 1 bird), $24 \%$ crustaceans, and some echinoderms and other invertebrates. It is also well known that the eider duck eats blue mussels (Mytilus edulis) and may be a nuisance to mussel farms. The cormorant, on the other hand, feeds mainly on fish. Witherby et al. (1965) report that up to $95.8 \%$ of the stomach contents of cormorants originated from different species of fish.

Acknowledgements. I am very grateful to O. Hansen for running the isotope analysis and to L. M. Hansen for phytoplankton samples from the Norwegian Sea. I also thank K. Dunton and his co-workers, and 3 anonymous referees for comments that improved the manuscript. Thanks also to K. M. Norderhaug for help with the statistics and to J. F. Larsen for processing the samples. This investigation was supported by the Research Council of Norway.

\section{LITERATURE CITED}

Christie H, Fredriksen S, Rinde E (1998) Regrowth of kelp and colonization of epiphyte and fauna community after kelp trawling at the coast of Norway. Hydrobiologia 375/376: 49-58

Dale T, Rey F, Heimdal BR (1999) Seasonal development of phytoplankton at a high latitude oceanic site. Sarsia 84 : 419-435

Dauby P, Khomsi A, Bouquegneau J (1998) Trophic relationships within intertidal communities of the Brittany coast: a stable carbon isotope analysis. J Coast Res 14:1202-1212

Dawson TE, Mambelli S, Plamboeck AH, Templer PH, Tu KP (2002) Stable isotopes in plant ecology. Annu Rev Ecol Syst 33:507-559
DeNiro MJ, Epstein S (1978) Influence of diet on the distribution of carbon isotopes in animals. Geochim Cosmochim Acta 42:495-506

Duggins DO, Eckman JE (1997) Is kelp detritus a good food for suspension feeders? Effect of kelp species, age and secondary metabolites. Mar Biol 128:489-495

Duggins DO, Simenstad CA, Estes JA (1989) Magnification of secondary production by kelp detritus in coastal marine ecosystems. Science 245:170-173

Dunton KH, Dayton PK (1995) The biology of high latude kelp. In: Skjoldal HR, Hopkins C, Erikstad KE, Leinaas HP (eds) Ecology of fjords and coastal waters. Elsevier, Amsterdam, p 499-507

Dunton KH, Schell DM (1987) Dependence of consumers on macroalgal (Laminaria solidungula) carbon in an arctic kelp community: $\delta^{13} \mathrm{C}$ evidence. Mar Biol 93:615-625

Fosså JH (1995) Management of kelp. Prioritized research activities. Institute of Marine Research, Bergen, Norway (In Norwegian with English abstract)

Fosså JH, Christie H, Sjøtun K (1998) Laminaria hyperborea beds as feeding chamber for fish. Abs 16th Int Seaweed Symp, Philippines

Fry B (1988) Food web structure on Georges Bank from stable C, N, and S isotopic compositions. Limnol Oceanogr 33: 1182-1190

Fry B, Sherr E (1984) $\delta^{13} \mathrm{C}$ measurements as indicators of carbon flow in marine and freshwater ecosystems. Contrib Mar Sci 27:13-47

Hargrave BT, Burns NM (1979) Assessment of sediment trap collection efficiency. Limnol Oceanogr 24:1124-1136

Hayward PJ, Wigham GD, Yonow N (1995) Molluscs. In: Hayward PJ, Ryland JS (eds) Handbook of the marine fauna of North-West Europe. Oxford University Press, Oxford, p 484-628

Hobson KA, Welch HE (1992) Determination of trophic relationships within a high Arctic marine food web using $\delta^{13} \mathrm{C}$ and $\delta^{15} \mathrm{~N}$ analysis. Mar Ecol Prog Ser 84:9-18

Hobson KA, Ambrose WG, Renaud PE (1995) Sources of primary production, benthic-pelagic coupling, and trophic relationships within the Northeast Water Polynya: insights from $\delta^{13} \mathrm{C}$ and $\delta^{15} \mathrm{~N}$ analysis. Mar Ecol Prog Ser 128:1-10

Jennings S, Warr KJ, Mackinson S (2002) Use of size-based production and stable isotope analyses to predict trophic transfer efficiencies and predator-prey body mass ratios in food webs. Mar Ecol Prog Ser 240:11-20

Kaehler S, Pakhomov EA, McQuaid CD (2000) Trophic structure of the marine food web at the Prince Edward Islands (Southern Ocean) determined by $\delta^{13} \mathrm{C}$ and $\delta^{15} \mathrm{~N}$ analysis. Mar Ecol Prog Ser 208:13-20

Kain JM (1971) Synopsis of biological data on Laminaria hyperborea. FAO Fish Synop 87:1-68

Kübler JE, Raven JA (1994) Consequences of light limitation for carbon acquisition in three rhodophytes. Mar Ecol Prog Ser 110:203-209

Lesage V, Hammill MO, Kovacs KM (2001) Marine mammals and the community structure of the Estuary and Gulf of St Lawrence, Canada: evidence from stable isotope analysis. Mar Ecol Prog Ser 210:203-221

Mann KH (2000) Ecology of coastal waters. With implications for management. Blackwell Scientific Publications, Oxford

Martel A, Diefenbach T (1993) Effects of body size, water current and microhabitat on mucous-thread drifting in post-metamorphic gastropods Lacuna spp. Mar Ecol Prog Ser 99:215-220

McConnaughey T, McRoy CP (1979) ${ }^{13} \mathrm{C}$ label identifies eelgrass (Zostera marina) carbon in an Alaskan estuarine food web. Mar Biol 53:263-269 
McKinney FK (1990) Feeding and associated colonial morphology in marine bryozoans. Rev Aquat Sci 2:255-280 Moore PG (1986) Levels of heterogeneity and the amphipod fauna of kelp holdfasts. In: Moore PG, Seed R (eds) Ecology of rocky coasts. Hodder \& Stoughton, London, p 274-289

Norderhaug KM, Fredriksen S, Nygaard K (2003) Trophic importance of Laminaria hyperborea to kelp forest consumers and the importance of bacterial degradation to food quality. Mar Ecol Prog Ser 255:135-144

Norton TA, Hiscock K, Kitching JA (1977) The ecology of Lough Ine. XX. The Laminaria forest at Carrigathorna. J Ecol 65:919-941

Peterson BJ, Howarth RW, Garritt RH (1985) Multiple stable isotopes used to trace the flow of organic matter in estuarine food webs. Science 227:1361-1363

Rau GH, Ainley DG, Bengston JL, Torres JJ, Hopkins TL (1992) ${ }^{15} \mathrm{~N} /{ }^{14} \mathrm{~N}$ and ${ }^{13} \mathrm{C} /{ }^{12} \mathrm{C}$ in Weddell Sea birds, seals and fish: implications for diet and trophic structure. Mar Ecol Prog Ser 84:1-8

Raven JA, Johnston AM, Kübler JE, Korb R and 8 others (2002) Mechanistic interpretation of carbon isotope discrimination by marine macroalgae and seagrasses. Funct Plant Biol 29:355-378

Rolff C (2000) Seasonal variation in $\delta^{13} \mathrm{C}$ and $\delta^{15} \mathrm{~N}$ of sizefractionated plankton at a coastal station in the northern Baltic proper. Mar Ecol Prog Ser 203:47-65

Ryland JS (1995) Fish. In: Hayward PJ, Ryland JS (eds) Handbook of the marine fauna of North-West Europe. Oxford University Press, Oxford, p 712-757

Schaffelke B, Lüning K (1994) A circannual rhythm controls

Editorial responsibility: Otto Kinne (Editor),

Oldendorf/Luhe, Germany seasonal growth in kelps Laminaria hyperborea and $L$. digitata from Helgoland (North Sea). Eur J Phycol 29: $49-56$

Schoschina EV (1997) On Laminaria hyperborea (Laminariales, Phaeophyceae) on the Murman coast of the Barents Sea. Sarsia 82:371-373

Schultze K, Janke K, Krüss A, Weidemann W (1990) The macrofauna and macroflora associated with Laminaria digitata and L. hyperborea at the island of Helgoland (German Bight, North Sea). Helgol Meeresunters 44:39-51

Sjøtun K, Fredriksen S, Rueness J, Lein TE (1995) Ecological studies of the kelp Laminaria hyperborea (Gunnerus) Foslie in Norway. In: Skjoldal HR, Hopkins C, Erikstad KE, Leinaas HP (eds) Ecology of fjords and coastal waters. Elsevier, Amsterdam, p 525-536

Sjøtun K, Fredriksen S, Rueness J (1996) Seasonal growth and carbon and nitrogen content in canopy and first-year plants of Laminaria hyperborea (Laminariales, Phaeophyta). Phycologia 35:1-8

Stephenson RL, Tan FC, Mann KH (1984) Stable carbon isotope variability in marine macrophytes and its implications for food web studies. Mar Biol 81:223-230

Vander Zanden JM, Rasmussen JB (1999) Primary consumer $\delta^{13} \mathrm{C}$ and $\delta^{15} \mathrm{~N}$ and the trophic position of aquatic consumers. Ecology 80:1395-1404

Vander Zanden JM, Shuter BJ, Lester N, Rasmussen JB (1999) Patterns of food chain lengths in lakes: a stable isotope study. Am Nat 154:406-416

Witherby HF, Jourdain FCR, Ticehurst NF, Tucker BW (1965) The handbook of British birds. Vols III \& IV. HF \& G Witherby, London

Submitted: February 7, 2002; Accepted: July 15, 2003 Proofs received from author(s): September 12, 2003 